\title{
LPA rs 10455872 polymorphism is associated with coronary lesions in Brazilian patients submitted to coronary angiography
}

\author{
Paulo CJL Santos ${ }^{1 *}$, Carolina T Bueno ${ }^{1}$, Pedro A Lemos ${ }^{2}$, José E Krieger ${ }^{1}$ and Alexandre C Pereira ${ }^{1 *}$
}

\begin{abstract}
Background: Polymorphisms in the LPA gene were associated with coronary artery disease (CAD). However, there are differences in the allelic frequencies, Lp(a) levels, and significant association with CAD according to ethnic groups. In this scenario, the main aim of this study was to assess the influence of the LPA polymorphisms on coronary lesions in Brazilian patients.

Methods: 1,394 consecutive patients submitted to coronary angiography to study suggestive CAD and twenty coronary segments were scored. Genotyping for the LPA rs10455872 and rs3798220 polymorphisms were performed by high resolution melting analysis.

Results: The frequencies of the rs10455872 G and rs3798220 C variant alleles were $6.4 \%$ and $6.2 \%$, respectively. LPA rs $10455872 \mathrm{G}$ variant allele was associated with higher odds ratio of having coronary lesions in an adjusted model $(\mathrm{OR}=2.02,95 \% \mathrm{Cl}=1.10-3.72, \mathrm{p}=0.02)$. Scores of coronary lesions (extension, severity, and Gensini scores) were significantly different among rs10455872 genotype groups. Coronary lesions was not associated with LPA rs3798220 $(\mathrm{OR}=1.09,95 \% \mathrm{Cl}=0.67-1.76, \mathrm{p}=0.73)$ and scores of coronary lesions were not different among $\mathrm{rs} 3798220$ genotypes.
\end{abstract}

Conclusions: We confirmed the association of the LPA rs 10455872 with CAD in a large sample of Brazilian patients. For the LPA rs3798220, our finding is consistent with studies which showed the lack of this genetic association.

Keywords: LPA gene, rs10455872, rs3798220, Coronary lesions, Coronary artery disease

\section{Introduction}

Lipoprotein(a) $[\mathrm{Lp}(\mathrm{a})]$ is a plasma lipoprotein synthesized by the liver that is composed of a low-density lipoprotein (LDL) molecule, a high molecular weight glycoprotein apolipoprotein(a), and a single molecule of apolipoprotein (B). Physiological and pathogenic roles of $\mathrm{Lp}(\mathrm{a})$ remain partially unknown. Studies have suggested that Lp(a) provides a link between the cholesterol transport and the fibrinolytic system acting as a modulator of the blood clotting and fibrinolysis systems $[1,2]$.

The increased concentration of $\mathrm{Lp}(\mathrm{a})$ has been associated with incidence and severity of cardiovascular disease $(\mathrm{CVD})$, coronary artery disease (CAD), peripheral

\footnotetext{
*Correspondence: pacaleb@usp.br; alexandre.pereira@incor.usp.br 'Laboratory of Genetics and Molecular Cardiology, Heart Institute (InCor), University of Sao Paulo Medical School, Av. Dr. Enéas de Carvalho Aguiar, 44 Cerqueira César, São Paulo, SP CEP 05403-000, Brazil

Full list of author information is available at the end of the article
}

artery disease, and stroke [3-7]. A meta-analysis of published data from 31 prospective studies reported a relative risk for coronary heart disease of $1.60(95 \% \mathrm{CI}=$ 1.38-1.85) associated with $\operatorname{Lp}(\mathrm{a})$ levels $[8,9]$.

More than $90 \%$ of the variance of $\mathrm{Lp}(\mathrm{a})$ concentration is explained by genetic variation [1]. A genome-wide association study showed that there is a group of genes strongly associated with CAD, such as solute carrier family 22 member 3 (SLC22A3), lipoprotein(a)-like 2 (LPAL2), and lipoprotein(a) $(L P A)$, but investigators did not identify the functional variants at these loci [10-12].

Two polymorphisms in the LPA gene (rs3798220 and rs 10455872) were associated with risk for CAD. However, there are differences in the allelic frequencies, $\mathrm{Lp}$ (a) levels, and degree of association with CAD according to ethnic groups [13-18]. In this scenario, the main aim of this study was to assess the influence of the LPA 
polymorphisms on coronary lesions in Brazilian patients submitted to coronary angiography.

\section{Patients and methods}

\section{Patients submitted to coronary angiography}

One thousand three hundred and ninety-four consecutive patients submitted to coronary angiography to study suggestive CAD were selected at the Laboratory of Hemodynamic, Heart Institute (InCor), Sao Paulo, Brazil. All patients had a clinical diagnosis of angina pectoris and stable angina. No patient enrolled in this study was currently experiencing an acute coronary syndrome. Patients with heart failure classes III-IV, hepatic dysfunction, familiar hypercholesterolemia, previous heart or kidney transplantation, and in antiviral treatment were excluded $[19,20]$. All patients signed an informed consent form and the protocol was approved by the ethics committee from Hospital das Clínicas from São Paulo University (CAPPesq 0398/04).

\section{Demographic data and laboratory tests}

Data regarding general characteristic, weight, height, race/ color, main cardiovascular risk factors (hypertension, diabetes, obesity, dyslipidemia, smoking, and current medical treatment) were obtained by interview. Race/color was classified as White, Brown (Pardo in Portuguese; person with admixture between White and Black), Black or Asiatic [21].

Triglycerides, total cholesterol (TC), high-density lipoprotein cholesterol, LDL cholesterol, and glucose were evaluated by standard techniques in 12-h fasting blood samples. Diabetes mellitus was diagnosed by the presence of fasting glucose $\geq 126 \mathrm{mg} / \mathrm{dL}$ or the use of antidiabetic drugs [22]. Hyperlipidemia was defined as TC $\geq 240 \mathrm{mg} / \mathrm{dL}, \mathrm{LDL}-\mathrm{C} \geq$ $160 \mathrm{mg} / \mathrm{dL}$, and/or use of lipid-lowering drugs [23].

\section{Hemodynamic and angiographic data}

Blood pressure was measured in the sitting position with the use of a standard mercury sphygmomanometer on the left arm after 5 min rest. The first and fifth phases of Korotkoff sounds were used for systolic blood pressure (SBP) and diastolic blood pressure (DBP), respectively. The SBP and DBP were calculated from two readings with a minimal interval of $10 \mathrm{~min}$ apart. Hypertension was defined as mean SBP $\geq 140 \mathrm{~mm} \mathrm{Hg}$ and/or DBP $\geq 90 \mathrm{~mm} \mathrm{Hg}$ and/or antihypertensive drug use [24].

Twenty coronary segments were scored: each vessel was divided into three segments (proximal, medial, and distal), except for the secondary branches of the right coronary artery (posterior ventricular and posterior descending), which were divided into proximal and distal segments. Stenosis higher than $50 \%$ in any coronary segment was graded 1 point and the sum of points for all 20 segments constituted the Extension Score. Lesion severity was calculated as follows: none and irregularities, 0 points; <50\%, 0.3 points; $50-70 \%, 0.6$ points; > 70-90\%, 0.8 points; and $>90-100 \%, 0.95$ points. The Severity Score was calculated through the sum of points for all 20 coronary segments [25].

\section{Genotyping}

Genomic DNA from subjects was extracted from peripheral blood following standard salting-out procedure. Additional file 1: Figure S1 shows genotyping detected by polymerase chain reaction (PCR) followed by high resolution melting (HRM) analysis with the Rotor Gene $6000^{\circ}$ instrument (Qiagen, Courtaboeuf, France). The QIAgility $^{\circ}$ (Qiagen, Courtaboeuf, France), an automated instrument, was used according to instructions to optimize the sample preparation step [26].

Amplification of the fragment for the LPA rs10455872 (A > G, intron 25) polymorphism was performed using the primer sense $5^{\prime}$ - ATGGGCTGGCAACACATAG $3^{\prime}$ and antisense 5' - CACTTTCTCCTCTAACCTGTA TAA -3' (78 pairs base). Amplification of the fragment for the LPA rs3798220 ( $\mathrm{T}>\mathrm{C}$, p.Ile1891Met) polymorphism was performed using the primer sense $5^{\prime}$ GGCTCCAAGAACAGCCTAGA $-3^{\prime}$ and antisense 5' - TCCTCAAGGCCTTCATCCTA -3' (104 pairs base). A 40-cycle PCR was carried out with the following conditions: denaturation of the template DNA for first cycle of $94^{\circ} \mathrm{C}$ for $120 \mathrm{~s}$, denaturation of $94^{\circ} \mathrm{C}$ for $20 \mathrm{~s}$, annealing of $56.7^{\circ} \mathrm{C}$ for $20 \mathrm{~s}$, and extension of $72^{\circ} \mathrm{C}$ for $22 \mathrm{~s}$. PCR was performed with addition of fluorescent DNA-intercalating SYTO9 $^{\circ}(1.5 \mu \mathrm{M}$; Invitrogen, Carlsbad, USA). In the HRM phase, the Rotor Gene $6000^{\circ}$ measured the fluorescence in each $0.1^{\circ} \mathrm{C}$ temperature increase in the range of $72-81^{\circ} \mathrm{C}$. Melting curves were generated by the decrease in fluorescence with the increase in the temperature; and in analysis, nucleotide changes result in three different curve patterns (Additional file 1: Figure S1). Samples of the three observed curves were analyzed using bidirectional sequencing as a validation procedure (ABI Terminator Sequencing $\mathrm{Kit}^{\oplus}$ and ABI 3500XL Sequencer ${ }^{\bullet}$ - Applied Biosystems, Foster City, CA, USA) [27]. The two methods gave identical results in all tests. The wild-type, heterozygous and mutant homozygous genotypes could be easily discernible by HRM analysis. In addition, 4\% of the samples were randomly selected and reanalyzed as quality controls and gave identical results.

\section{Statistical analysis}

Categorical variables are presented as percentage while continuous variables are presented as mean \pm standard deviation. Chi-square test was performed for comparative analysis of general characteristics and coronary lesion frequency according to LPA polymorphisms. Dominant models $(A G+G G)$ for the rs10455872 or $(T C+C C)$ for the rs3798220 were performed because the frequencies of 
the GG and CC homozygous genotypes are low. Student's t-test was performed for comparing the age, body mass index (BMI), biochemical data, blood pressures, and angiographic data means according to $L P A$ polymorphisms. Biochemical data, blood pressures, and angiographic data were adjusted for age, gender, and race/color. Logistic regression univariate and multivariate analyses were performed to evaluate OR (odds ratio) for coronary lesions. Two adjusted models were performed: one using age, gender, and race/ color and another with the additional covariates BMI, hyperlipidemia, statin use, and smoking. Linkage disequilibrium, Hardy-Weinberg equilibrium, and haplotype analyses were conducted with Haploview 4.0. All statistical analyses were carried out using the SPSS software (v. 16.0), with the level of significance set at $\mathrm{p} \leq 0.05$.

\section{Results}

\section{General characteristics and LPA polymorphisms}

Of the 1,394 patients, mean age of $59.7 \pm 10.4,1,126$ $(80.8 \%)$ had coronary lesions indicated by coronary angiography. The frequency of the rs $10455872 \mathrm{G}$ variant allele was $6.4 \%$ and the distribution of the genotypes was $0.6 \%(n=8)$ for variant homozygous, $11.7 \%(n=163)$ for heterozygous and $87.7 \%(n=1223)$ for wild-type. The frequency of the rs $3798220 \mathrm{C}$ variant allele was $6.2 \%$ and the distribution of the genotypes was $0.4 \%(n=6)$ for variant homozygous, $11.6 \%(\mathrm{n}=165)$ for heterozygous and $88.0 \%$ $(\mathrm{n}=1248)$ for wild-type. The genotypic distribution for the LPA rs10455872 and rs3798220 polymorphisms were in accordance with the Hardy-Weinberg equilibrium $\left(\mathrm{X}^{2}=1.01, \mathrm{p}=0.31\right.$ and $\mathrm{X}^{2}=0.05, \mathrm{p}=0.82$, respectively $)$. Linkage disequilibrium analysis shows that the LPA rs3798220 and rs10455872 variant alleles had no strong disequilibrium ( $L D=73$ ) (Additional file 2: Figure S2).

\section{Biochemical, hemodynamic, and angiographic data according to LPA rs 10455872 polymorphism}

Table 1 shows data from patients submitted to coronary angiography according to $L P A$ rs10455872 genotypes. The frequency of the LPA rs10455872 AG or GG genotypes was lower in non-Whites compared with Whites $(p=0.02)$. Patient carrying AG or GG genotypes had higher TC mean and proportion of hyperlipidemia. Regarding the angiographic data, higher frequency of coronary lesions $(\mathrm{p}=0.004)$ was found in patients with AG or GG genotypes (88.9\%) compared to patient with AA genotype (79.6\%). Also, scores of coronary lesions (extension, severity, and Gensini scores) were significantly different among genotype groups $(\mathrm{p}<0.001, \mathrm{p}<0.001$, and $\mathrm{p}=0.05$, respectively) (Table 1$)$.

Furthermore, the presence of the LPA rs $10455872 \mathrm{G}$ variant allele was associated with higher OR of having coronary lesion, which we compared normal coronary arteries versus one-vessel, two-vessel, and three-vessel disease. Table 2
Table 1 General characteristics, biochemical, hemodynamic, and angiographic data according to LPA rs 10455872 genotypes in the patients submitted to coronary angiography

\begin{tabular}{|c|c|c|c|}
\hline \multirow[b]{2}{*}{$(n=1394,100 \%)$} & \multicolumn{2}{|c|}{ Genotypes } & \multirow[t]{2}{*}{$p$ value } \\
\hline & $\begin{array}{c}A A \\
(n=1223)\end{array}$ & $\begin{array}{l}A G+G G \\
(n=171)\end{array}$ & \\
\hline Age (years) & $59.9 \pm 10.1$ & $59.5 \pm 10.8$ & 0.62 \\
\hline Gender, female (\%) & 40.6 & 37.4 & 0.42 \\
\hline \multicolumn{4}{|l|}{ Race/color (\%) } \\
\hline White & 65.0 & 74.9 & \\
\hline Intermediate & 29.8 & 23.4 & 0.02 \\
\hline Black & 5.2 & 1.8 & \\
\hline Hypertension (\%) & 70.0 & 68.4 & 0.68 \\
\hline Diabetes (\%) & 31.2 & 27.5 & 0.33 \\
\hline Hyperlipidemia (\%) & 57.2 & 71.3 & 0.002 \\
\hline Statin use (\%) & 28.0 & 30.5 & 0.61 \\
\hline Smokers (\%) & 35.6 & 38.0 & 0.44 \\
\hline Body mass index $\left(\mathrm{Kg} / \mathrm{m}^{2}\right)$ & $27.7 \pm 4.8$ & $27.6 \pm 4.9$ & 0.99 \\
\hline Total cholesterol (mg/dL) & $228 \pm 49$ & $237 \pm 46$ & 0.05 \\
\hline LDL-C (mg/dL) & $147 \pm 44$ & $155 \pm 39$ & 0.11 \\
\hline HDL-C (mg/dL) & $42 \pm 12$ & $42 \pm 10$ & 0.82 \\
\hline Triglycerides (mg/dL) & $183 \pm 130$ & $179 \pm 108$ & 0.75 \\
\hline Systolic blood pressure $(\mathrm{mmHg})$ & $149 \pm 34$ & $152 \pm 39$ & 0.61 \\
\hline Diastolic blood pressure $(\mathrm{mmHg})$ & $82 \pm 15$ & $84 \pm 15$ & 0.29 \\
\hline Ejection fraction (\%) & $60.6 \pm 14.4$ & $56.8 \pm 17.7$ & 0.07 \\
\hline Coronary lesions (\%) & 79.6 & 88.9 & 0.004 \\
\hline Extension score & $2.1 \pm 1.6$ & $2.6 \pm 1.7$ & $<0.001$ \\
\hline Severity score & $1.5 \pm 1.2$ & $1.9 \pm 1.3$ & $<0.001$ \\
\hline Gensini score & $19.7 \pm 28.2$ & $25.7 \pm 32.0$ & 0.05 \\
\hline
\end{tabular}

HDL-C: high density lipoprotein; LDL-C: low density lipoprotein.

Biochemical data, blood pressures, and angiographic scores were adjusted for age, gender, and race/color.

Coronary lesions frequency was compared between normal coronary arteries versus one-vessel, two-vessel, and three-vessel disease.

shows three models, being the OR of $2.02(95 \% \mathrm{CI}=1.10$ $3.72, \mathrm{p}=0.02$ ) in an adjusted model with age, gender, race/ color, BMI, hyperlipidemia, statin use, and smoking. Also, Additional file 3: Table S1 shows logistic regression univariate analysis of the OR for coronary lesions. Additional file 4: Table S2 shows significant association for the variables age (as a continuous variable presented in the Table or as categorical variable - median age of 61 years as a cut-off resulting in an $\mathrm{OR}$ of $1.88,95 \% \mathrm{CI}=1.43-2.47, \mathrm{p}<0.001$ ), gender, BMI, statin use, and hyperlipidemia in a logistic regression multivariate analysis.

\section{Analysis stratified by race for the LPA rs 10455872 polymorphism}

In the White group ( $\mathrm{n}=901)$, patients with AG or GG genotypes $(n=128)$ had higher frequency of coronary lesions 


\begin{tabular}{|c|c|c|c|}
\hline$(n=1394,100 \%)$ & OR & $95 \% \mathrm{Cl}$ & $p$ value \\
\hline \multicolumn{4}{|l|}{ Models } \\
\hline Unadjusted & 2.04 & $1.24-3.36$ & 0.005 \\
\hline Adjusted* & 2.05 & $1.22-3.43$ & 0.006 \\
\hline Adjusted $^{* *}$ & 2.02 & $1.10-3.72$ & 0.02 \\
\hline
\end{tabular}

Coronary lesions frequency was compared between normal coronary arteries versus one-vessel, two-vessel, and three-vessel disease.

${ }^{*}$ Adjusted for age, gender, and race/color.

${ }^{* *}$ Adjusted for age, gender, race/color, body mass index, hyperlipidemia, statin use, and smoking.

compared to patient with AA genotype $(\mathrm{n}=773)(90.6 \%$ and $81.0 \%$, respectively, $\mathrm{p}=0.008$ ). The presence of the LPA rs10455872 G variant allele was associated with higher OR of having coronary lesion in an adjusted model $(\mathrm{OR}=2.17,95 \% \mathrm{CI}=1.04-4.61, \mathrm{p}=0.03)$. Also, scores of coronary lesions were significantly different among genotype (extension: $2.7 \pm 1.6$ and $2.2 \pm 1.6$; severity: $1.9 \pm 1.3$ and $1.6 \pm 1.2$; and Gensini scores: $26.3 \pm 30.0$ and $19.7 \pm$ 29.8) $(\mathrm{p}=0.001, \mathrm{p}=0.01$, and $\mathrm{p}=0.04$, respectively).

In the non-White group $(n=460$, formed for Black and Brown individuals), frequency of coronary lesions was not statistically different $(83.7 \%$ for AG or GG genotypes and $77.0 \%$ for AA genotype, $\mathrm{p}=0.30$ ). However, the presence of the $G$ variant allele was associated with higher $\mathrm{OR}(\mathrm{OR}=$ $1.95,95 \% \mathrm{CI}=1.09-4.39, \mathrm{p}=0.04$ - adjusted model) and scores of coronary lesions were different between AG or GG and AA genotypes (extension score: $2.6 \pm 1.7$ and $2.0 \pm$ 1.6; and severity score: $1.9 \pm 1.3$ and $1.4 \pm 1.2)(\mathrm{p}=0.04$, and $\mathrm{p}=0.03$, respectively). Gensini score was marginally different between genotypes $(24.7 \pm 29.6$ and $21.2 \pm 27.5$; $\mathrm{p}=0.06)$.

\section{Biochemical, hemodynamic, and angiographic data according to LPA rs3798220 polymorphism}

The proportion of hyperlipidemia was not different among rs3798220 genotypes $(\mathrm{p}=0.62)$. Regarding the angiographic data, the frequency of coronary lesions was not associated with rs3798220 $(\mathrm{p}=0.57)$ and no significant $\mathrm{OR}$ was observed in an adjusted model $(\mathrm{OR}=$ $1.09,95 \% \mathrm{CI}=0.67-1.76, \mathrm{p}=0.73)$. Also, scores of coronary lesions (extension, severity, and Gensini scores) were not significantly different among genotype groups $(\mathrm{p}=0.85, \mathrm{p}=0.56$, and $\mathrm{p}=0.46$, respectively $)$.

\section{Discussion}

The two $L P A$ polymorphisms studied in this study are some of the most important genetic markers for CAD. In this context, our main finding was that the $L P A$ rs10455872 polymorphism is associated with coronary lesions in Brazilian patients submitted to coronory angiography. On the other hand, no association for the
$L P A$ rs3798220 was observed for any of the tested phenotypes.

Studies have reported higher $\mathrm{Lp}(\mathrm{a})$ concentration in sub-Saharan African descent and lower Lp(a) concentration in European descent $[13,15,28,29]$. Regarding the ethnicity, Brazil has one of the most heterogeneous population of the world, composed by a mixture of different ethinic groups, mainly European descent, African descent and Amerindians. In our data, a stratified analysis by race supported a role for the rs 10455872 polymorphism independent of ethnic group.

Corroboring with our study, Anderson et al. found that the rs10455872 polymorphism strongly predicted prevalent $\mathrm{CAD}$ (per allele $\mathrm{OR}=1.43,95 \% \mathrm{CI}=1.07-1.91$ ) [30]. Helgadottir et al. showed that patients with CAD carrying LPA risk alleles have increased susceptibility to atherosclerotic manifestations outside of the coronary tree and they are more likely to be diagnosed earlier with CAD than are CAD cases not carrying this variant [31]. Other studies that analyzed the rs 10455872 and rs3798220 polymorphisms together reported an increased risk of coronary disease and $\mathrm{Lp}(\mathrm{a})$ level that can be explained by these LPA polymorphisms [11,32]. LPA rs10455872 is an intronic polymorphism associated with short KIV-2 repeat region (kringle IV type 2) which is associated with $\mathrm{Lp}(\mathrm{a})$ levels. In the present study, the frequency of the rs $10455872 \mathrm{G}$ variant allele was $6.4 \%$ for overall, but we observed higher allelic frequency in White compared with non-White groups. The association of the rs10455872 with CAD was significant even in the non-White group which had a small sample size. These data suggest that rs 10455872 is also a strong genetic marker for CAD risk in ethnically mixed populations.

For the LPA rs3798220 polymorphism, we did not observe significant association with coronary lesions. Data from other studies also did not support a relationship between this LPA variant and CAD [33,34]. Furthermore, Anderson et al., studying 1,400 participants with coronary angiography (more than 90\% Whites), did not find an association signal between $\mathrm{rs} 3798220$ and $\mathrm{CAD}(\mathrm{OR}=1.47$, $95 \% \mathrm{CI}=0.81-2.67, \mathrm{p}=0.20$ ) [30]. In contrast to our study, the rs3798220 has previously been reported to have an association with the $\mathrm{Lp}(\mathrm{a})$ level and the risk of coronary disease [35-37]. LPA rs3798220 results in an aminoacid substitution in the protease domain of $L P A$, but it can not provide stronger association than rs10455872 which might be representating a more complex group of genetic variants or repeat structures. A possible hypothesis for the lack of this association in the present study could be the lower value of linkage disequilibrium between rs3798220 and rs10455872 identified in the Brazilian patients compared with some studies with patients predominantly from European descent [11,35-37]. Another hypothesis may be low statistical power, but less likely if the impact of 
rs3798220 was approximately equal to the impact of rs10455872. However, the exact reason is unclear and other genetic components differently expressed due to ethnicity might be important modulators.

The exact mechanism by which an increased $L p(a)$ level increases the CAD risk is not fully understood. Pathways modulated by Lp(a) may involve the LDLcholesterol transport system, the inhibition of the expression of tissue factor, the inhibition of conversion of plasminogen to plasmin, the carriage of pro-inflammatory oxidized phospholipids, and an atherosclerotic stenotic mechanism [30,38-44]. Some studies reported that the severity of coronary artery disease is associated with $\mathrm{Lp}(\mathrm{a})$ levels or LDL concentration [45-48]. Regarding to the Lp(a) level as a risk factor in different ethnic groups, $L p(a)$ has been associated with risk in European populations [1], but not unequivocally in African Americans [17,18]. However, a recent study identified that the increased risk of CVD was at least as strong in African Americans as in White Americans [49]. Another study investigated differential frequencies of $L P A$ polymorphisms in non-Hispanic whites, non-Hispanic blacks, and Mexican Americans [50]. Interestingly, 15 of the 19 polymorphisms tested were strongly associated with $\mathrm{Lp}(\mathrm{a})$ levels in at least one subpopulation, six in at least two subpopulations, and none in all three subpopulations. The lack of generalization of associations across ethnicities suggests that specific $L P A$ variants may be contributing to the observed $\mathrm{Lp}$ (a) between-population variance. Authors also compared the allele frequencies in HapMap, and observed extremely high correlations $(r \geq 0.99)$ in allele frequencies between non-Hispanic whites and HapMap CEU (US individuals of northern and western European ancestry) and between non-Hispanic blacks and both HapMap YRI (Yoruba from West Africa) and ASW (individuals with African ancestry from the Southwest USA) [50].

There are some limitations in our study. First, we did not measure $\mathrm{Lp}(\mathrm{a})$ levels and we also did not genotype KIV-2 repeats to check their association with both the LPA polymorphisms and/or the CAD phenotype. Second, we did not assess ancestry through genetic markers; instead, we used a self-declared classification which is commonly applied in Brazil and correlates with genetic ancestry determination. In addition, in our stratified analysis by race, we observed significant association of the rs10455872 with CAD in the White and non-White patient groups. Third, our plaque burden data are derived from institutional records and represent real-life data, as opposed to core-lab derived hemodinamic data. Thus, and despite the greater external validity of our results, we were not able to determine inter- or intra-observed variability estimates. In addition, our choosen method for establishing atherosclerotic burden in the studied patients has relied upon the Gensini Score, which has been shown to highly correlate with this end-point. Other scores could also be used, although they are not as well fitted for quantifing plaque burden. One example is the Syntax score, an angiographic tool for grading the complexity of CAD and designed to better anticipate the risks of percutaneous or surgical revascularization. Finnaly, it is not possible to completely exclude the interaction of the covariates as other genetic markers, use of concomitant drugs, ethnicity, gender and age on our findings [51-54]. Nonetheless, our findings remained after multivariate analysis.

\section{Conclusions}

In conclusion, we confirmed the association of the $L P A$ rs10455872 with CAD in a large sample of Brazilian patients. For the $L P A$ rs3798220, our finding is consistent with studies which showed the lack of this genetic association.

\section{Additional files}

Additional file 1: Figure S1. Graphs of the LPA rs10455872 (A>G intron 25) genotyping. Nucleotide changes results in different curve patterns using high resolution melting analysis. A: Graph of normalized fluorescence by temperature. B: Graph of normalized fluorescence (based on genotype 2) by temperature. 1: wild-type genotype (AA); 2: heterozygous genotype (AG); 3: mutant homozygous genotype (GG).

Additional file 2: Figure S2. Linkage disequilibrium and haplotype analyses for the LPA rs3798220 and rs10455872 polymorphisms in the patients submitted to coronary angiography.

Additional file 3: Table S1. Logistic regression univariate analysis of the coronary lesions odds ratio in the patients submitted to coronary angiography.

Additional file 4: Table S2. Logistic regression multivariate analysis of the coronary lesions odds ratio in the patients submitted to coronary angiography.

\section{Competing interests}

The authors declare that they have no competing interests.

\section{Authors' contributions}

PCJLS and CTB carried out molecular genetic analyses, performed the statistical analysis and drafted the manuscript. PCJLS, ACP, PAL, JEK conceived the study, and participated in its design. All authors read and approved the final manuscript.

\section{Acknowledgments}

PCJL Santos is recipient of fellowship from FAPESP, Proc. 2013-09295-3, and Proc. 2013-20614-3, Brazil. We also thank the patients who participated in the study. The technical assistance of the Laboratory of Genetics and Molecular Cardiology group is gratefully acknowledged.

\section{Author details}

'Laboratory of Genetics and Molecular Cardiology, Heart Institute (InCor), University of Sao Paulo Medical School, Av. Dr. Enéas de Carvalho Aguiar, 44 Cerqueira César, São Paulo, SP CEP 05403-000, Brazil. 'Hemodynamic Laboratory, Heart Institute (InCor), University of Sao Paulo Medical School, Sao Paulo, Brazil.

Received: 8 March 2014 Accepted: 22 April 2014

Published: 29 April 2014 


\section{References}

1. Kronenberg F, Utermann G: Lipoprotein(a): Resurrected by genetics. J Intern Med 2013, 273:6-30.

2. Koschinsky ML: Novel insights into Ip(a) physiology and pathogenicity: More questions than answers? Cardiovasc Hematol Disord Drug Targets 2006, 6:267-278.

3. Erqou S, Kaptoge S, Perry PL, Di Angelantonio E, Thompson A, White IR, Marcovina SM, Collins R, Thompson SG, Danesh J, Collaboration ERF: Lipoprotein(a) concentration and the risk of coronary heart disease, stroke, and nonvascular mortality. JAMA 2009, 302:412-423.

4. Tsimikas S, Mallat Z, Talmud PJ, Kastelein JJ, Wareham NJ, Sandhu MS, Miller ER, Benessiano J, Tedgui A, Witztum JL, Khaw KT, Boekholdt SM: Oxidationspecific biomarkers, lipoprotein(a), and risk of fatal and nonfatal coronary events. J Am Coll Cardiol 2010, 56:946-955.

5. Danesh J, Collins R, Peto R: Lipoprotein(a) and coronary heart disease. Meta-analysis of prospective studies. Circulation 2000, 102:1082-1085.

6. Klein JH, Hegele RA, Hackam DG, Koschinsky ML, Huff MW, Spence JD: Lipoprotein(a) is associated differentially with carotid stenosis, occlusion, and total plaque area. Arterioscler Thromb Vasc Biol 2008, 28:1851-1856.

7. Ohira T, Schreiner PJ, Morrisett JD, Chambless LE, Rosamond WD, Folsom AR: Lipoprotein(a) and incident ischemic stroke: The atherosclerosis risk in communities (aric) study. Stroke 2006, 37:1407-1412.

8. Bennet A, Di Angelantonio E, Erqou S, Eiriksdottir G, Sigurdsson G, Woodward M, Rumley A, Lowe GD, Danesh J, Gudnason V: Lipoprotein(a) levels and risk of future coronary heart disease: Large-scale prospective data. Arch Intern Med 2008, 168:598-608.

9. Nestel PJ, Barnes EH, Tonkin AM, Simes J, Fournier M, White HD, Colquhoun DM, Blankenberg S, Sullivan DR: Plasma lipoprotein(a) concentration predicts future coronary and cardiovascular events in patients with stable coronary heart disease. Arterioscler Thromb Vasc Biol 2013, 33:2902-2908.

10. Trégouët DA, König IR, Erdmann J, Munteanu A, Braund PS, Hall AS, Grosshennig A, Linsel-Nitschke P, Perret C, DeSuremain M, Meitinger T, Wright BJ, Preuss M, Balmforth AJ, Ball SG, Meisinger C, Germain C, Evans A, Arveiler D, Luc G, Ruidavets JB, Morrison C, van der Harst P, Schreiber S, Neureuther K, Schäfer A, Bugert P, El Mokhtari NE, Schrezenmeir J, Stark K, et al: Genome-wide haplotype association study identifies the slc22a3-Ipal2-Ipa gene cluster as a risk locus for coronary artery disease. Nat Genet 2009, 41:283-285.

11. Clarke R, Peden JF, Hopewell JC, Kyriakou T, Goel A, Heath SC, Parish S, Barlera S, Franzosi MG, Rust S, Bennett D, Silveira A, Malarstig A, Green FR, Lathrop M, Gigante B, Leander K, De Faire U, Seedorf U, Hamsten A, Collins R, Watkins H, Farrall M, Consortium P: Genetic variants associated with $\mathrm{lp}(\mathrm{a})$ lipoprotein level and coronary disease. N Engl J Med 2009, 361:2518-2528.

12. Hopewell JC, Clarke R, Parish S, Armitage J, Lathrop M, Hager J, Collins R, Group HPSC: Lipoprotein(a) genetic variants associated with coronary and peripheral vascular disease but not with stroke risk in the heart protection study. Circ Cardiovasc Genet 2011, 4:68-73.

13. Chretien JP, Coresh J, Berthier-Schaad Y, Kao WH, Fink NE, Klag MJ, Marcovina SM, Giaculli F, Smith MW: Three single-nucleotide polymorphisms in Ipa account for most of the increase in lipoprotein(a) level elevation in african americans compared with european americans. J Med Genet 2006, 43:917-923.

14. Lanktree MB, Anand SS, Yusuf S, Hegele RA, Investigators S: Comprehensive analysis of genomic variation in the lpa locus and its relationship to plasma lipoprotein(a) in south asians, chinese, and european caucasians. Circ Cardiovasc Genet 2010, 3:39-46

15. Deo RC, Wilson JG, Xing C, Lawson K, Kao WH, Reich D, Tandon A, Akylbekova E, Patterson N, Mosley TH, Boerwinkle E, Taylor HA: Singlenucleotide polymorphisms in Ipa explain most of the ancestry-specific variation in Ip(a) levels in african americans. PLoS One 2011, 6:e14581.

16. Mooser V, Scheer D, Marcovina SM, Wang J, Guerra R, Cohen J, Hobbs HH: The apo(a) gene is the major determinant of variation in plasma Ip(a) levels in african americans. Am J Hum Genet 1997, 61:402-417.

17. Paultre F, Pearson TA, Weil HF, Tuck CH, Myerson M, Rubin J, Francis CK, Marx HF, Philbin EF, Reed RG, Berglund L: High levels of Ip(a) with a small apo(a) isoform are associated with coronary artery disease in african american and white men. Arterioscler Thromb Vasc Biol 2000, 20:2619-2624.

18. Moliterno DJ, Jokinen EV, Miserez AR, Lange RA, Willard JE, Boerwinkle E, Hillis LD, Hobbs HH: No association between plasma lipoprotein(a) concentrations and the presence or absence of coronary atherosclerosis in african-americans. Arterioscler Thromb Vasc Biol 1995, 15:850-855.

19. Maciel SS: Pereira Ada C, Silva GJ, Rodrigues MV, Mill JG, Krieger JE: Association between glutathione s-transferase polymorphisms and triglycerides and hdl-cholesterol. Atherosclerosis 2009, 206:204-208.
20. Santos PC, Oliveira TG, Lemos PA, Mill JG, Krieger JE, Pereira AC: Mylip p.N342s polymorphism is not associated with lipid profile in the brazilian population. Lipids Health Dis 2012, 11:83.

21. Santos PC, Alvim Rde O, Ferreira NE, De Sa Cunha R, Krieger JE, Mill JG, Pereira AC: Ethnicity and arterial stiffness in brazil. Am J Hypertens 2011, 24:278-284.

22. Executive summary: Standards of medical care in diabetes-2011. Diabetes Care 2011, 34(Suppl 1):S4-S10.

23. Executive summary of the third report of the national cholesterol education program (ncep) expert panel on detection, evaluation, and treatment of high blood cholesterol in adults (adult treatment panel iii). JAMA 2001, 285:2486-2497.

24. The seventh report of the joint national committee on prevention, detection, evaluation, and treatment of high blood pressure. JAMA 2003, 2004

25. Lanz JR, Pereira AC, Martinez E, Krieger JE: Metabolic syndrome and coronary artery disease: Is there a gender specific effect? Int I Cardiol 2006, 107:317-321

26. Santos PC, Soares RA, Santos DB, Nascimento RM, Coelho GL, Nicolau JC, Mill JG, Krieger JE, Pereira AC: Cyp2c19 and abcb1 gene polymorphisms are differently distributed according to ethnicity in the brazilian general population. BMC Med Genet 2011, 12:13

27. Santos PC, Soares RA, Nascimento RM, Machado-Coelho GL, Mill JG, Krieger JE, Pereira AC: SIco1b1 rs4149056 polymorphism associated with statin-induced myopathy is differently distributed according to ethnicity in the brazilian general population: Amerindians as a high risk ethnic group. BMC Med Genet 2011, 12:136.

28. Cobbaert C, Kesteloot H: Serum lipoprotein(a) levels in racially different populations. Am J Epidemiol 1992, 136:441-449.

29. Utermann G: Genetic architecture and evolution of the lipoprotein(a) trait. Curr Opin Lipidol 1999, 10:133-141.

30. Anderson JL, Knight S, May HT, Horne BD, Bair TL, Huntinghouse JA, Rollo $J S$, Muhlestein JB, Carlquist JF: Validation and quantification of genetic determinants of lipoprotein-a levels and predictive value for angiographic coronary artery disease. Am J Cardiol 2013, 112:799-804.

31. Helgadottir A, Gretarsdottir S, Thorleifsson G, Holm H, Patel RS, Gudnason T, Jones GT, van Rij AM, Eapen DJ, Baas AF, Tregouet DA, Morange PE, Emmerich J, Lindblad B, Gottsäter A, Kiemeny LA, Lindholt JS, Sakalihasan N, Ferrell RE, Carey DJ, Elmore JR, Tsao PS, Grarup N, Jørgensen T, Witte DR, Hansen T, Pedersen O, Pola R, Gaetani E, Magnadottir HB, et al: Apolipoprotein(a) genetic sequence variants associated with systemic atherosclerosis and coronary atherosclerotic burden but not with venous thromboembolism. J Am Coll Cardiol 2012, 60:722-729.

32. Ronald J, Rajagopalan R, Cerrato F, Nord AS, Hatsukami T, Kohler T, Marcovina S, Heagerty P, Jarvik GP: Genetic variation in Ipal2, Ipa, and plg predicts plasma lipoprotein(a) level and carotid artery disease risk. Stroke 2011, 42:2-9.

33. Li ZG, Li G, Zhou YL, Chen ZJ, Yang JQ, Zhang Y, Sun S, Zhong SL: Lack of association between lipoprotein(a) genetic variants and subsequent cardiovascular events in chinese han patients with coronary artery disease after percutaneous coronary intervention. Lipids Health Dis 2013, 12:127.

34. Lv X, Zhang Y, Rao S, Liu F, Zuo X, Su D, Wang M, Xia M, Guo H, Feng D, Hong C, Li D, Ma W, Ouyang P, Li X, Feng X, Yang Y, Ling W, Qiu J: Lack of association between four snps in the slc22a3-Ipal2-Ipa gene cluster and coronary artery disease in a chinese han population: A case control study. Lipids Health Dis 2012, 11:128.

35. Luke MM, Kane JP, Liu DM, Rowland CM, Shiffman D, Cassano J, Catanese JJ, Pullinger CR, Leong DU, Arellano AR, Tong CH, Movsesyan I, Naya-Vigne J, Noordhof C, Feric NT, Malloy MJ, Topol EJ, Koschinsky ML, Devlin JJ, Ellis SG: A polymorphism in the protease-like domain of apolipoprotein(a) is associated with severe coronary artery disease. Arterioscler Thromb Vasc Biol 2007, 27:2030-2036.

36. Chasman DI, Shiffman D, Zee RY, Louie JZ, Luke MM, Rowland CM, Catanese JJ, Buring JE, Devlin JJ, Ridker PM: Polymorphism in the apolipoprotein(a) gene, plasma lipoprotein(a), cardiovascular disease, and low-dose aspirin therapy. Atherosclerosis 2009, 203:371-376

37. Li Y, Luke MM, Shiffman D, Devlin Jj: Genetic variants in the apolipoprotein (a) gene and coronary heart disease. Circ Cardiovasc Genet 2011, 4:565-573.

38. Kathiresan S, Willer CJ, Peloso GM, Demissie S, Musunuru K, Schadt EE, Kaplan L, Bennett D, Li Y, Tanaka T, Voight BF, Bonnycastle LL, Jackson AU, 
Crawford G, Surti A, Guiducci C, Burtt NP, Parish S, Clarke R, Zelenika D, Kubalanza KA, Morken MA, Scott L, Stringham HM, Galan P, Swift AJ, Kuusisto J, Bergman RN, Sundvall J, Laakso M, et al: Common variants at 30 loci contribute to polygenic dyslipidemia. Nat Genet 2009, 41:56-65.

39. Caplice NM, Panetta C, Peterson TE, Kleppe LS, Mueske CS, Kostner GM, Broze GJ, Simari RD: Lipoprotein (a) binds and inactivates tissue factor pathway inhibitor: A novel link between lipoproteins and thrombosis. Blood 2001, 98:2980-2987.

40. Grainger DJ, Kemp PR, Liu AC, Lawn RM, Metcalfe JC: Activation of transforming growth factor-beta is inhibited in transgenic apolipoprotein(a) mice. Nature 1994, 370:460-462.

41. Tsimikas S, Brilakis ES, Miller ER, McConnell JP, Lennon RJ, Kornman KS, Witztum JL, Berger PB: Oxidized phospholipids, Ip(a) lipoprotein, and coronary artery disease. N Engl J Med 2005, 353:46-57.

42. Koschinsky ML, Marcovina SM: Structure-function relationships in apolipoprotein(a): Insights into lipoprotein(a) assembly and pathogenicity. Curr Opin Lipidol 2004, 15:167-174.

43. Miles LA, Plow EF: $\operatorname{Lp}(\mathrm{a})$ : An interloper into the fibrinolytic system? Thromb Haemost 1990, 63:331-335.

44. Cushing GL, Gaubatz JW, Nava ML, Burdick BJ, Bocan TM, Guyton JR, Weilbaecher D, DeBakey ME, Lawrie GM, Morrisett JD: Quantitation and localization of apolipoproteins [a] and $\mathrm{b}$ in coronary artery bypass vein grafts resected at re-operation. Arteriosclerosis 1989, 9:593-603.

45. Malek F, Dvorak J, Svitil J, Skalnikova V, Mates M, Kmonicek P, Formanek P, Aschermann O, Kopriva K, Neuzil P: Correlation of lipoprotein(a) concentration with the extent of coronary artery disease in patients on lipid lowering therapy. Neuro Endocrinol Lett 2012, 33(Suppl 2):55-59.

46. Moon JY, Kwon HM, Kwon SW, Yoon SJ, Kim JS, Lee SJ, Park JK, Rhee JH, Yoon YW, Hong BK, Rim SJ, Kim HS: Lipoprotein(a) and Idl particle size are related to the severity of coronary artery disease. Cardiology 2007, 108:282-289.

47. Miller NE, Hammett F, Saltissi S, Rao S, van Zeller H, Coltart J, Lewis B: Relation of angiographically defined coronary artery disease to plasma lipoprotein subfractions and apolipoproteins. Br Med J (Clin Res Ed) 1981, 282:1741-1744

48. Brilakis ES, McConnell JP, Lennon RJ, Elesber AA, Meyer JG, Berger PB: Association of lipoprotein-associated phospholipase a2 levels with coronary artery disease risk factors, angiographic coronary artery disease, and major adverse events at follow-up. Eur Heart J 2005, 26:137-144.

49. Virani SS, Brautbar A, Davis BC, Nambi V, Hoogeveen RC, Sharrett AR, Coresh J, Mosley TH, Morrisett JD, Catellier DJ, Folsom AR, Boerwinkle E, Ballantyne CM: Associations between lipoprotein(a) levels and cardiovascular outcomes in black and white subjects: The atherosclerosis risk in communities (aric) study. Circulation 2012, 125:241-249.

50. Dumitrescu L, Glenn K, Brown-Gentry K, Shephard C, Wong M, Rieder MJ, Smith JD, Nickerson DA, Crawford DC: Variation in Ipa is associated with Ip(a) levels in three populations from the third national health and nutrition examination survey. PLoS One 2011, 6:e16604.

51. Ferreira NE, Omae S, Pereira A, Rodrigues MV, Miyakawa AA, Campos LC, Santos PC, Dallan LA, Martinez TL, Santos RD, Mill JG, Krieger JE, Pereira AC: Thioredoxin interacting protein genetic variation is associated with diabetes and hypertension in the brazilian general population. Atherosclerosis 2012, 221:131-136.

52. Alvim RO, Santos PC, Ferreira NE, Mill JG, Krieger JE, Pereira AC: Thioredoxin interacting protein (txnip) rs7212 polymorphism is associated with arterial stiffness in the brazilian general population. J Hum Hypertens 2012, 26:340-342.

53. De Oliveira AR, Santos PC, Musso MM, De Sá CR, Krieger JE, Mill JG, Pereira AC: Impact of diabetes mellitus on arterial stiffness in a representative sample of an urban brazilian population. Diabetol Metab Syndr 2013, 5:45.

54. Santos PC, Morgan AC, Jannes CE, Turolla L, Krieger JE, Santos RD, Pereira AC: Presence and type of low density lipoprotein receptor (Idlr) mutation influences the lipid profile and response to lipid-lowering therapy in brazilian patients with heterozygous familial hypercholesterolemia. Atherosclerosis 2014, 233:206-210.

doi:10.1186/1476-511X-13-74

Cite this article as: Santos et al.: LPA rs 10455872 polymorphism is associated with coronary lesions in Brazilian patients submitted to coronary angiography. Lipids in Health and Disease 2014 13:74.

\section{Submit your next manuscript to BioMed Central and take full advantage of:}

- Convenient online submission

- Thorough peer review

- No space constraints or color figure charges

- Immediate publication on acceptance

- Inclusion in PubMed, CAS, Scopus and Google Scholar

- Research which is freely available for redistribution 